\title{
Konsep Spiritual Quotient Menurut Danah Zohar dan Ian Marshall Dalam Perspektif Pendidikan Islam
}

\author{
Arin Muflichatul Matwaya*1, Ahmad Zahro ${ }^{* 2}$. \\ ${ }^{1}$ Universitas Hasyim Asy'ari \\ ${ }^{1}$ Universitas Pesantren Tinggi Darul Ulum \\ e-mail: arinmuflichatulmastwaya@gmail.com.prof.zahro@gmail.com,
}

Submitted: 12-06-2020Ｒevised : 17-08-2020 Accepted: 20-09-2020

\begin{abstract}
Spiritual Quotient (SQ), which is the foundation needed to function Intelligent Quotient (IQ) and Emotional Quotient (EQ) effectively. Even SQ is the highest intelligence. So that humans who have high SQ are a category of people who have noble morals. So Islamic education will play a role in aspects of humanity which can actually be maximized through SQ sensitivity. This study is intended to answer the following problems: (1) What is the General Concept of Spiritual Quotient? (2) What is the Concept of Spiritual Quotient in the Perspective of Islamic Education? These problems are discussed through library data collection, reading, taking notes, and processing research materials. This scientific work is a type of library research research, which is a series of activities related to the methods of collecting library data, reading, taking notes, and processing research materials which are library research or pure research. All data were analyzed using a philosophical approach. This study shows that: (1) Spiritual intelligence (SQ) means the ability to know and understand ourselves fully as spiritual beings and as part of the universe. Having spiritual intelligence means that we fully understand the meaning and essence of the life we live and where humans are going. Based on these two concepts, it shows that Western SQ is more oriented towards the completion and achievement of world happiness, while Islamic SQ is more about achieving happiness in the world and the hereafter. If both are used ideally, SQ can be implemented in order to achieve "happiness" both in this world and in the hereafter. (2) The concept of Spiritual Quotient in the perspective of Islamic education is spirituality education that can sharpen the quality of spiritual intelligence, namely the values of spirituality itself which are aimed at education.
\end{abstract}

Keywords: Spiritual Quotient (SQ), Danah Zohar \& Ian Marshall, Islamic Education.

\begin{abstract}
How to Cite Matwaya, A. M., \& Zahro, A. . (2020). Konsep Spiritual Quotient Menurut Danah Zohar dan Ian Marshall Dalam Perspektif Pendidikan Islam. Attadrib: Jurnal Pendidikan Guru Madrasah Ibtidaiyah, 3(2), 41-48.
\end{abstract}

\section{INTRODUCTION}

Konsep manusia dalam dunia pendidikan dilihat sebagai makhluk yang lengkap terdiri dari unsur jasmani - ruhani, jiwa-akal, nafs-qolb (Naim, 2012; Naim \& Patoni, 2007). Karena itu dalam diri manusia ada potensi untuk berhubungan dengan dunia materi dan spiritual. Secara kodrati manusia adalah makhluk yang paling sempurna diantara makhluk-makhluk ciptaan Allah yang lainnya. Kelebihan ini karena manusia dibekali dengan akal, jiwa dan hati nurani yang sempurna. Hakekat manusia sebagai makhluk yang paling tinggi derajatnya mendorong manusia untuk terus maju dan berkembang tanpa henti; dani zaman ke zaman(Fajriana \& Aliyah, 2019; Ma'arif, 2017).

Kecerdasan Intelektual diperoleh melalui olah akal. Kecerdasan emosional diperoleh melalui olah "jiwa". Sedangkan, kecerdasan spiritual diperoleh dengan olah qolbu. Oleh qolbu 
inilah yang acapkali diabaikan oleh manusia. Tatkala, manusia acuh untuk memenuhi kebutuhan dari spiritual (basic spiritual needs), maka manusia akan tertimpa krisis spiritual (crisis spiritual). Kekeringan spiritual inilah biang dani semua krisis.

Pengaruh pendidikan moderen yang cenderung mengedepankan Kecerdasan Intelektual (IQ) menjadikan masyarakat selalu berfikir rasional dan sistematis keberhasilan anak akan dinilai baik ketika anak mendapatkan nilai dengan angka besar. Doktrin intellectualism sudah ditanamkan oleh orang tua, guru dan sistem pendidikan pada anak sejak masih kecil, ketika jiwa masih mudah untuk dibentuk. Sekolah adalah tempat orang yang mencari ilmu untuk peserta didik yang bersekolah tapi kecenderungan lembaga disekolah adalah membentuk kecerdasan intelektual atau yang disebut IQ. bagian besar dari peserta didik yang ber Intelegent Quetent menjadi peserta didik yang berhasil namun padahal sebenarnya itu tidak menentukan. Peserta didik ketika mempunyai kecerdesan intelektual atau IQ sederhana saja tergolong lebih simpel untuk berteman dengan sesamanya, menolong antar sesama, setia terhadap kawan - kawannya, bertanggung jawab dalam segala hal, dan selalu ramah tamah. bagian besar yang ber IQ tinggi cenderung kurang pandai bergaul dengan sebayanya, tidak mempunyai perasaan atau dinamakan egois dengan inilah disebut Emosional Quetion (EQ) adalah serangkaian kecakapan untuk melapangkan jalan di dunia yang penuh penderitaan dan permasalahan sosial. Meskipun, masih ada nilai - nilai yang tidak dapat dipungkiri keberadaanya atau situasinya yaitu kecerdasan spritual (SQ) yang memberi pelajaran tentang nilai-nilai kebenaran. makna kebenaran adalah yang memahamkan nilai yang terdapat dalam kehidupan sesuai dengan suara spiritual yang dihasilkan oleh SQ (Daud, 2012; M Syaroni, 2018).

Tujuan penting dalam kehidupan seluruh umat manusia adalah pendidikan. Dengan begitu pendidikan sangatlah penting bagi umat manusia yang secara tidak langsung dapat melepaskan dari proses proses untuk mencari pendidikan, dengan adanya untuk ikut dalam proses pendidikan lah setiap manusia dapat mencari kemampuan dna bakat masing - masng agar dapat bertahaan hidup dan memproleh kehidupaan yang pantas dan selayaknya didunia ini (Akhtar et al., 2017; Ma`arif \& Sulistyanik, 2019).

Pendidikan bukan hanya berarti pewarisan nilai-nilai budaya berupa kecerdasan dan ketrampilan dari generasi tua ke generasi muda, tetapi juga berarti mengembangkan berbagai potensi-potensi individu untuk kegunaan individu itu sendiri dan selanjutnya untuk kebahagiaan masyarakat(Zulaikhah et al., 2020).

Pada hakikatnya pendidikan merupakan sarana yang dapat meningkatkan taraf hidup manusia. Melalui pendidikan, para generasi penerus bangsa diharapkan mampu mewujudkan perilaku belajar yang baik. Perilaku belajar merupakan tanggapan atau reaksi peserta didik terhadap rangsangan atau lingkungan belajarnya yang menyangkut aspek kognitif, afektif dan psikomotorik sebagai akibat dari pengalaman dan latihan.

Hal inilah yang menjadi motivasi utama penulis untuk melakukan penelitian lebih lanjut untuk mencari format tentang "KONSEP SPIRITUAL QUOTIENT MENURUT DANAH ZOHAR dan IAN MARSHALL DALAM PERSPEKTIF PENDIDIKAN ISLAM”.

\section{METHOD}

Pendekatan yang digunakan adalah pendekatan filosofis (Philosopical Approach) salah satu ciri khas yang ditonjolkan dala penelitian ini adalah dapat mengkaji ide-ide dasar serta pemikiran yang fundamental yang dirumuskan oleh seorang pemikir atau tokoh. Dengan kata lainperumusan setruktur dan conseptual analisis adalah ciri khas pendekatan filosofis yang tidak perlu terganggu oleh faktor faktor skunder.

Jenis penelitian ini adalah penelitian pustaka (Library research), yaitu penelitian yang obyek utamanya dengan mengguanakan bahan-bahan tertulis seperti manuskrip, buku, majaah, surat 
kabar, dan dokumen atau sumber kepustakaan lainnya (Zed, 2008). Maksudnya, data dicari dan ditemukan melalui kajian pustaka dari buku - buku yang relevan dengan pembahasan, selain dari buku, data dalam penelitian ini juga dapat di peroleh dari jurnal (Bryman, 2012).

\section{RESULT AND DISCUSSION}

\section{Result}

Danah Zohar dibesarkan oleh kakek-neneknya selama tahun 1950-an di Midwest Amerika. Mereka adalah orang-orang yang sangat religius, dan taat, yang telah mengenal kemiskinan dan penderitaan sepanjang hidup mereka dan selamat dari depresi besar. Kakeknya adalah seorang pria yang membanggakan, dicintai dan dipercaya oleh masyarakat, seorang pria pada siapa orang tahu mereka bisa mengandalkan. Kakek tidak pernah mengecewakan orang-orang disekelilingnya. Itulah adalah kakek Danah Zohar yang tertanam kode moral sengit dalam diri nya. Zohar ragu orangorang mengingat janji-janjinya. Ini dibuat pada dorongan, tampaknya tulus berarti pada saat ini, tapi kemudian cepat dilupakan. Dalam hidup Zohar, selama beberapa tahun terakhir, kelupaan instan seperti pada bagian sesorang yang telah membuat janji dengan Zohar atau orang lain, Zohar tahu telah menjadi norma. Zohar sudah menyimpulkan bahwa terlalu sering orang hanya berjanji maka tidak dapat diandalkan.

Zohar menghabiskan banyak waktunya bekerja di dunia bisnis. Dan untuk menjalankan perusahaan terlibat dengan orang lain dan meminta, dan mengandalkan, kepercayaan. Untuk terlibat dalam bisnis sama sekali adalah untuk menerima bahwa seseorang memiliki tanggung jawab untuk memenuhi kontrak satu dan membayar pajak seseorang, tanggung jawab kepada pelanggan, karyawan, pemegang saham dan idealnya, kepada masyarakat dan lingkungan. Tapi kontrak berselingkuh atau tidak puas, celah pajak dicari, barang dan jasa jelek yang ditawarkan kepada pelanggan, dan pemegang saham ditipu oleh bonus eksekutif yang besar dan korupsi di atas. Dalam sebagian besar kasus, biarkan masyarakat dan lingkungan terkutuk. Bank tidak bisa lagi dipercaya, dan politisi tidak akan pernah bisa.

Sedangkan Ian Marshall nama lengkapnya Ian Paul Marshall. Marshall lahir pada tanggal 20 Maret tahun 1966, dan saat ini berumur 47 tahun tempat lahir Liverpool, Inggris tinggi badannya $1.86 \mathrm{~m}$ (Zohar, 2010, 2012).

\section{Latar Belakang Pendidikan Danah Zohar dan Ian Marshall}

Danah Zohar dan Ian Marshall adalah sepasang suami istri yang aktif dan produktif menulis buku dan menjadi pemandu lokakarya internasional. Mereka saat ini menetap di London, Inggris. Danah Zohar sendiri dilahirkan dan mengenyam pendidikan di Amerika. Zohar adalah sarjana fisika dan filsafat dani MIT (Massachusett Institut of Tekhnologi). Dan saat ini sedang menyelesaikan post graduate di bidang agama, filsafat dan psikologi di Havard. Ia menjadi tenaga pengajar di oxvord strategic leadership program di Oxvord University dan program leading edge di Oxvord Brookes University.

Sedangkan Ian Marshall adalah seorang psikiater, psikoterapis dan penulis beberapa makaalah akademik mengenai sifat pikiran. Ia meraih gelar dalam bidang psikologi dan filsafat di Oxvord University dan mengambil gelar medisnya di London. Dari merekalah konsep Spiritual Quotient; Spiritual Intelligence yang menarik minat banyak kalangan diperkenalkan. Melalui karya ilmiah mereka yang monumental dengan judul "SQ : Intelligence Spiritual : The Ultimate Intelligence" terbit pertengahan tahun 2000. Sebagaimana diungkapkan Zohar dan Marshall, ada beberapa hal yang mendasari lahirnya konsep kecerdasan spiritual ini diantaranya adalah kondisi masyarakat moderen terutama di dunia barat yang tidak mampu merasakan kebahagian hidup yang disebabkan karena mengalami krisis spiritual dan kehilangan makna hidup. 
Konstruksi SQ (Spiritual Quotient) yang dibangun Zohar dan Marshall mendasarkan pada penemuan penelitian para ahli neorolog dan psikolog tentang aktivitas otak manusia. Terutama penemuan dani Micheal Passinger dan VS Ramanchandran tentang aktivitas God Spot atau "Titik Tuhan" yang berada di daerah temporal (lobus temporal) otak manusia. Konsep SQ ini pada dasarnya adalah upaya pengembangan lebih luas dani beberapa gagasan para psikolog. Seperti gansan Viktor Frakl tentang logoterapi (aliran psikologi humanistik) dan C.G. Jung dengan psikologi transpersonalnya

\section{Karya-karya Danah Zohar dan Ian Marshall}

Danah Zohar dan Ian Marshall baik bersama ataupun sendirian telah banyak memberikan sumbangan pemikiran yang tidak kecil dalam perkembangan ilmu pengetahuan dewasa ini. Terutama dalarn bidang filsafat dan psikologi. Pada umumnya karya-karya mereka lebih terfokus pada kajian tentang pikiran dan otak manusia. Zohar dan Marshall telah menerbitkan buku-buku seperti, The Quantum Self The Quantum Society, Who Is Afraid of Scorodiger is Cat dan Reasoning the Corperate Brain.

Buku pertama mereka terbit pada tahun 1990 "The Quantum Self" Bloomsbury, London. Karya mereka ini merupakan dobrakan terhadap "Elitisme Fisika Quantum" yang oleh Fritjof Copra dilebur dengan "Elitisme Mistik Timur" menjadi "Elitisme Mistisisme Zaman Baru". Dalam bukunya, Zohar dan Marshall meletakkan proses quantum di tengah-tengah kehidupan kita selaarihari dengan menyatakan, bahwa proses berpikir kita yang biasa sehari-hari bukan hanya pengalaman mistik yang esoteris, melainkan pada dasamya adalah proses quantum. Dilanjutkan dengan buku yang kedua "The Quantum Society" terbit tahun 1999 Flaminggo, London. Dalam buku kedua ini mereka mengatakan, bahwa masyarakat dunia hams ditata kembali menjadi masyarakat quantum yaitu sejumlah kumunitas-kumunitas kecil tatap muka yang berinteraksi secara dialogis serupa dengan model dialog internal yang terjadi dalam otak manusia. Mereka menyatakan, bahwa landasan fisika bagi keadaan manusia adalah proses kondensasi base einstein quatum, sel-sel syaraf yang menimbulkan koherensi gelombang listrik magnet di otak.

\section{Kecerdasan Spiritual Danah Zohar dan Ian Marshall}

Pertengahan tahun 2000 dunia pendidikan dan psikologi dihenyakkan dengan penemuan barat moderen tentang ukuran kecerdasan manusia setelah Intelektual Quotient dan Emosional Quotient yang mereka sebut dengan Spiritual Intelligence atau Spiritual Quotient. Spiritual Intelligence banyak menarik minat masyarakat bias tak terkecuali para tokoh Agama, termasuk para ulama Islam.

Hal ini disebabkan karena penggunaan istilah "Spiritual" yang biasanya identik dengan Agama yang disematkan dalam ukuran kecerdasan tersebut. Masalah spiritualitas manusia sebenamya bukan hal yang baru. Sejak lama hal ini telah disadari oleh para ahli psikologi. Banyak tokoh-tokoh yang telah mengkaji masalah ini, semisal Wiliam James dengan bukwiya yang monumental "The Varieties of Religion Experience" yang mendokumentasikan berbagai macam pengalaman spiritual/mistis dan Carl Gustav Jung yang secara tegas menyebutkan adanya bagian dalam diri manusia yang bersifat spiritual.

Dalam mengkaji kecerdasan spiritual (SQ) Zohar dan Marshall tidak memberikan batasan secara difinitif. Akan tetapi mereka memberikan gambaran-gambaran dan penjelasan-penjelesan yang kesemuanya berkaitan dengan esensi dari kecerdasan spiritual. Menurut mereka kecerdasan spiritual adalah kecerdasan yang dapat membantu manusia untuk menghadapi dan memecahkan berbagai persoalan yang berkaitan dengan masalah makna dan nilai. Sebuah kecerdasan yang akan membantu manusia untuk menempatkan tindakan dan hidupnya dalam konsteks makna yang lebih bias dan kaya. Ia adalah kecerdasan yang dapat dipergunakan untuk menilai bahwa tindakan hidup seseorang lebih bermakna dan bernilai dibandingkan dengan orang lain. Lebih dari itu, menurut mereka kecerdasan spiritual adalah "Ultimate Intelligence" kecerdasan tertinggi yang ada dan 
dimiliki manusia sekaligus sebagai syarat penting untuk dapat memfungsikan kecerdasan intelektual (IQ) dan kecerdasan emosional (EQ) secara efektive. Kecerdasan spiritual adalah perasaan terdalam akan makna dan nilai yang dapat mengantarkan manusia pada kesuksesan dan kebahagian hidup. Mereka juga mengatakan, Spiritual Quotient adalah "Our conscience" karena kecerdasan spiritual menurut mereka adalah "Soul Intelligence" yang dapat membantu manusia untuk membangun dirinya dengan utuh secara intelektual, emosional dan spiritual. Dan sebuah kecerdasan yang dapat menyembuhkan manusia dari penyakit spiritual (Spiritual Phatologi) dan berbagai ganggauan kesehatan mental (jiwa). Seperti keterpurukan, kehinaan, ketidakberdayaan, keputusasaan, kecemasan, depresi dan stres.

Dikatakan kecerdasan spiritual merupakan kecerdasan yang berada di luar diri yang mempunyai hubungan dengan kearifan di luar ego atau pikiran sadar. Ia adalah kesadaran yang tidak hanya mengakui nilai-nilai yang ada. Akan tetapi secara kreatif menemukan nilai-nilai baru. Karena kecerdasan spiritual tidak bergantung dengan budaya dan nilai-nilai yang telah ada dalam diri manusia, maka kecerdasan spiritual memungkinkan untuk menciptakan nilai-nilai itu sendiri.

Dengan demikian, maka kecerdasan spiritual akan mendahului budaya dan ekpresi agama apapun. Dalam kerangka inilah Zohar dan Marshall menyimpulkan bahwa, kecerdasan spiritual tidak mesti berhubungan dengan agama. Bagi sebagian kecerdasan spiritual mungkin menemukan cara pengungkapan melalui agama formal tetapi beragama tidak menjamin kecerdasan spiritual tinggi. Agam formal adalah seperangkat aturan dan kepercayaan yang dibebankan secara eksternal. Ia bersifat top down, diwarisi dari pendeta, nabi dan kitab suci atau ditanamkan melalui keluarga dan tradisi.

Menurut Zohar dan Marshall untuk memperoleh kebermaknaan hidup banyak jalan yang dapat di tempuh. Kata mereka salah satu jalan untuk menjadikan hidup manusia lebih bermakna adalah dengan beragama. Selain itu, manusia juga akan menemukan makna hidupnya melalui bekerja, belajar, menolong sesama, melakukan intropeksi dan mengadakan perenungan tentang dirii sendiri secara mendalam dan aktivitas-aktivitas lain yang bermanfaat bagi diri sendiri dan orang lain. bahkan menurut mereka seseorang dapat memperoleh kebermaknaan hidupnya ketika sedang menghadapi penderitaan, keterpurukan dan kesusahan atau saat seseorang menemukan solusi dani masalah yang sedang dihadapi.

Dari gambaran dan penjelasan yang diberikan Zohar dan Marshall di atas, jelaslah bahwa mereka menekankan pada aspek nilai dan makna sebagi unsur terpenting dalam kecerdasan spiritual. Dengan demikian jantung atau intisari dari pemikiran kecerdasan spiritual Zohar dan Marshall tidak lebih pada "Proses pemalaman hidup manusia untuk lebih bermakna". Unsur lain dari kecerdasan spiritual, menurut Zohar dan Marshall adalah transedensi diri. Transendensi adalah sesuatu yang membawa manusia "Mengatasi" (beyond) mengatasi masa kini, mengatasi rasa suka dan duka, bahkan mengatasi diri kita pada saat ini. la membawa kita melampui batas-batas pengetahuan dan pengalaman serta menempatkan pengetahuan dan pengalaman kita dalam konteks makna yang lebih luas.

\section{Konsep Spiritual Quotient Menurut Danah Zohar Dan Ian Marshall Dalam Perspektif Pendidikan Islam}

Manusia diciptakan oleh Allah untuk melalukan apa yang diperintahkannya sesuai apa yang tertulis didalam Al-Qur'an dan As-sunnah, melalui pikiran yang berupa akal, hati dan ruh. Dengan adanya itu manusia bisa membuktikan bahwa sebagai mahluk yang sempurna dari ciptaan Allah dari pada yang lainnya. Dari sudut pandang yang lain Manusia mempunyai arah untuk mengindikasikan berbagai banyak keahlian yang dimilikinya sesuai kemampuan intelegensi, emosi maupun spiritual. Semua bentuk kecerdasan yang dimiliki oleh manusia berakar pada potensi atau fitrah yang dianugerahkan oleh Allah. Demikian pula kecerdasan spiritual, dia bersumber dari fitrah manusia itu sendiri. Fitrah adalah akar Ilahiyah (original rood) yang diberikan Allah Swt. semenjak ditiupkannya ruh ke dalam rahim ibu. 
Berkaitan dengan SQ ini, temyata terdapat perbedaan dan persamaan antara tokoh yang kecenderungarmya religius dan non religius. Berbeda pula antara pendapat Danah Zohar sebagai tokoh Barat, dengan para tokoh Muslim seperti Al-Ghazali, Ari Ginanjar, dan lain-lain.

1. Sebelum mengetahaui Kecerdasan Spiritual Menurut Danah Zohar dan Ian Marshall dan lainnya, maka perlu kita ketahui tentang tanda-tanda Kecerdasan Spiritual yang telah berkembang dengan baik yaitu :
a. Kemampuan bersikap fleksibel (adaptif secara spontan dan aktif)
b. Tingkat kesadaran diri yang tinggi
c. Kemampuan untuk menghadapi dan memanfaatkan penderitaan
d. Kemampuan untuk menghadapi dan melampaui rasa sakit
e. Kualitas hidup yang diilhami oleh visi dan nilai-nilai
f. Keengganan untuk menyebabkan kerugian yang tidak perlu
g. Kecenderungan untuk melihat keterkaitan antara berbagai hal (berpandangan

"holistik")

h. Kecenderungan nyata untuk bertanya "mengapa"? atau "bagaimana"? untuk mencari jawaban jawan yang mendasar.

i. $\quad$ Menjadi apa yang disebut oleh para spikolog sebagai "bidang mandiri" yaitu memiliki kemudahan untuk bekerja melawan konvensi.

Indikator tersebut, bisa dipahami bahwa SQ lebih pada pencapaian kebahagian hidup dunia, yang meliputi ketenangan jiwa, berkepribadian, kesabaran menghadapi masalah dan rasa sakit, mampu memilih sesuatu yang perlu, dan bahkan mencari hakikat kebenaran permasalahan yang ada dengan kaca mata keduniawian.

Jadi, menurut Danah Zohar secara umum kita dapat meningkatkan SQ dengan meningkatkan penggunaan proses tersier psikologis kita yaitu kecenderungan kita untuk bertanya mengapa, untuk mencari keterkaitan antara segala sesuatu, untuk membawa ke permukaan asumsiasurnsi mengenai makna di balik atau di dalam sesuatu, menjadi lebih suka merenung, sedikit menjangkau di luar diri kita, bertanggung jawab, lebih sadar diri, lebih jujur terhadap diri sendiri, dan lebih pemberani

\section{Discussion}

Manusia berhasil atau tidaknya tidak tergantung oleh kecerdasan intelektual, melainkan oleh banyak jenis kecerdasan lainnya. Satu-satunya sumbangan yang paling penting dari pendidikan bagi pengembangan peserta didik adalah membantunya menemukan bidang yang paling cocok dengan keahlian dan bakatnya, yang akan membuat merasa puas dan kompeten.

Selama ini kecerdasan hanya dipahami seakan hanya berkaitan dengan kepandaian, sehingga digambarkan dengan ukuran-ukuran intelektualitas dan ilmu pengetahuan semata. Kalaupun kemudian aspek kecerdasan dihubungkan dengan masalah yang bernuansa spiritualitas, itupun masih di dalam tataran yang tidak substansial.

Pada konteks yang spesifik, kecerdasan spiritual merupakan kecerdasan untuk menghadapi dan memecahkan persoalan makna dan nilai hidup, menempatkan perilaku dalam konteks makna secara lebih luas dan kaya.

Kecerdasan merupakan kekuatan yang bersifat non material yang sangat diperlukan oleh manusia guna dijadikan sebagai alat bantu di dalam menjalani kehidupan di alam dunia. Kecerdasan dapat terbentuk melalui penyentuhan, pemolesan sampai dengan perekayasaan oleh 
sistem-sistem yang memang selaras. Sebab pada awalnya kecerdasan merupakan sebuah potensi yang tersembunyi dan tersimpan pada sejumlah unsur perangkat yang ada pada diri manusia. Salah satu yang memiliki kemampuan untuk dapat melakukan pemberdayaan dan menjadikan bermanfaatnya kecerdasan yang ada pada diri manusia adalah al-Qur'an al-Karim. Sebagaimana firman Allah SWT (Yusuf, 2016).

Ketika seseorang menjalani kehidupan ini dengan ingenius, palsu dan suka menipu, maka mereka pun menjadi diri yang palsu Kecerdasan spiritual mengajak dan bahkan membimbing seseorang menjadi diri yang genuine, yang asli dan autentik yang karenanya selalu mengalami harmoni Ilahi kehadirat Rabbi. Pengalaman harmoni spiritual kehadirat Tuhan dicapai dan sekaligus dirasakan dengan menggunakan apa yang dalam mistik spiritual disebut sebagai mata hati. SQ menyelami semua itu sebagai mata hati, karena mata hati dapat menyingkap kebenaran hakiki yang tak tampak oleh mata.

\section{CONCLUSION}

Dari paparan atau analisa bab-bab terdahulu penulis dapat menyimpulkan pembahasan tesis sebagai berikut:

Konsep Spritual Quotiont menurut Danah Zohar dan Ian Marshall yaitu kecerdasan untuk bisa menyesuaikan tingkah laku kehidupan manusia dalam keadaan berwawasan yang lebih luas dan tinggi, kecerdasan yang dapat menilai tindakan seseorang dalam kehidupan yang lebih berarti dari pada hal yang lainnya, maka dari itu kecerdasan spiritual menjadi sebab untuk menggali semua kemampuan manusia dan mengerti sepenuhnya sebagai mahluk yang bersepiritual tinggi maupun sebagai mahluk yang ada dimuka bumi ini. Manusia di bimbing untuk mempunyai sikap arif dan bijaksana dan itu lebih penting dari pada mempunyai IQ dan EQ. Danah Zohar dan Ian Marshall berpendapat tentang SQ bahwa penjelasan tersebut belum menyentuh tataran ketuhanan, hanya sebatas tataran biologi atau psikologi semata, tidak bersifat ruhaniyah yang berakibat masih adanya kebuntuan. Spiritual adalah salah satu yang berkaitan dengan kemampuan yang bisa memberikan semangat kepada manusia untuk menjalani kehidupan yang akan membawa manusia kearah yang benar dan seutuhnya dengan berfikir secara intregal dengan menjadikan tujuan hidupnya untuk mencapai kebahagiaan didunia maupun diakhirat. Manusia mempunyai semangat yang dapat dibangkitkan yang pada dasarnya dapat dibangun sebagai manusia beragama yang memiliki kekuatan untuk memhami proses kehidupan yang mana ada campur tangan dari Allah SWT. Kecerdasan spiritual mempunyai peranan untuk mencapai kesuksesan dan keberhasilan dalam pusat kecerdasan yang terletak pada hati nurani manusia. Kecerdasan spiritual selalu dimiliki manusia ketika manusia mampu untuk meningkatkan kecerdasan tersebut.

Konsep Spritual Quotiont menurut Danah Zohar dan Ian Marshall dalam prespektif pendidikan Islam yaitu berupa tentang keimanan, membaca syahadat adalah syarat utama untuk menjadi seorang muslim yang sejati, maka dari itu dalam ilmiahnya dinamakan hard ware dari spiritualitas adalah god spot, maka kecerdasan spiritual dalam prespektif pendidikan Islam merupakan muatan dari god spot tersebut. Cahaya ke-Ilahian menjadi tujuan dan motivasi utama dalam amalan setiap muslim. Konsep kecerdasan spiritual dalam perspektif pendidikan Islam merupakan Pendidikan spiritual yang dapat menajamkan kualitas kecerdasan spiritual, yaitu nilainilai spiritualitas itu sendiri yang di tujukan ke dalam pendidikan. Nilai-nilai yang dimaksud adalah kejujuran, keadilan, kebaikan, kebersamaan, kesetiakawanan sosial, dan masih banyak lagi. Nilainilai ini harus dileburkan kedalam diri peserta didik sejak usia dini. Nilai-nilai seperti kejujuran dan keteladanan moral yang baik itulah yang menjadi level tertinggi kecerdasan spiritual. Semakin baik dalam kejujuran dan keteladanan moral, maka akan semakin baik secara kualitatif. Sebagai makhluk yang beragama, kecerdasan spiritual dapat dibangun dengan menjalin hubungan untuk menjadi dekat dengan Tuhan. Kecerdasan spiritual juga mendidik hati ke dalam budi pekerti yang baik dan moral yang beradab yang efektif mendidik perilaku manusia yang rusak dan juga menjadi 
petunjuk manusia untuk menjalani hidup secara sopan dan beradab. Untuk itu, sebagai hamba Allah SWT., manusia harus menjalin hubungan baik dengan Tuhannya yakni mengabdikan dirinya kepada Allah (Hablum min Allah), sedangkan sebagai khalifah di muka bumi ia harus meninternalisasikan nilai-nilai spiritual.

\section{BIBLIOGRAPHY}

Akhtar, S., Arshad, M. A., Mahmood, A., \& Ahmed, A. (2017). Gaining recognition of Islamic spiritual intelligence for organisational sustainability. International Journal of Ethics and Systems, 34(1), 70-77. https://doi.org/10.1108/IJOES-01-2017-0003

Bryman, A. (2012). Social research methods (4th ed). Oxford University Press.

Daud, F. (2012). Pengaruh kecerdasan emosional (EQ) dan motivasi belajar terhadap hasil belajar Biologi siswa SMA 3 Negeri Kota Palopo. Jurnal Pendidikan Dan Pembelajaran (JPP), 19(2), 243-255.

Fajriana, A. W., \& Aliyah, M. A. (2019). Tantangan Guru dalam Meningkatan Mutu Pendidikan Agama Islam Di Era Melenial. Nað̧runa: Jurnal Pendidikan Islam, 2(2), 246-265. https://doi.org/10.31538/nzh.v2i2.324

M Syaroni, H. (2018). Kecerdasan Emosional Anak Sebagai Pertimbangan Dalam Pengembangan Perencanaan Pembelajaran PAI. Tarbawi, 5(1).

Ma`arif, M. A., \& Sulistyanik, E. D. (2019). PENGEMBANGAN POTENSI PESERTA DIDIK DALAM PEMBELAJARAN PENDIDIKAN AGAMA ISLAM BERBASIS KECERDASAN MAJEMUK (MULTIPLE INTELLIGENCE). Al-Tarbawi Al-Haditsab: Jurnal Pendidikan Islam, 4(2), Article 2. https://doi.org/10.24235/tarbawi.v4i2.5216

Ma'arif, M. A. (2017). Analisis Konsep Kompetensi Kepribadian Guru PAI menurut Az-Zarnuji. ISTAWA, 2(2), 35-60. http://journal.umpo.ac.id/index.php/istawa/article/view/624

Naim, N. (2012). Character Building: Optimalisasi Peran Pendidikan dalam Pengembangan Ilmu\& Pembentukan Karakter Bangsa,. Ar-Ruz Media.

Naim, N., \& Patoni, A. (2007). Materi Penyusunan Desain Pembelajaran Pendidikan Agama Islam (MPDP-PAI). Pustaka Pelajar.

Yusuf, M. Y. (2016). Peningkatan Esq (emotional-Spiritual Quotient) Melalui Tarekat Qodiriyah Wa Naqsabandiyah Di Pondok Pesantren Miftahul Huda Malang. Al-Qalam, 21(2), 263276.

Zed, M. (2008). Metode penelitian kepustakaan (Ed. 2). Yayasan Obor Indonesia.

Zohar, D. (2010). Exploring spiritual capital: An interview with Danah Zohar. Spirituality in Higher Education, 5(5), 1-8.

Zohar, D. (2012). Spiritual intelligence: The ultimate intelligence. Bloomsbury publishing.

Zulaikhah, D., Sirojuddin, A., \& Aprilianto, A. (2020). Analisis Pembelajaran Pendidikan Agama Islam Kurikulum 2013 Bagi Anak Berkebutuhan Khusus. Tafkir: Interdisciplinary Journal of Islamic Education, 1(1), 54-71. https://pasca.jurnalikhac.ac.id/index.php/tijie/article/view/6 